\title{
Environmental Monitoring and Assessment Program Western Pilot Project-Information About Selected Fish and Macroinvertebrates Sampled from North Dakota Perennial Streams, 2000-2003
}

\author{
Kevin C. Vining and Robert F. Lundgren
}

\section{Summary}

Sixty-five sampling sites, selected by a statistical design to represent lengths of perennial streams in North Dakota, were chosen to be sampled for fish and aquatic insects (macroinvertebrates) to establish unbiased baseline data. Channel catfish and common carp were the most abundant game and large fish species in the Cultivated Plains and Rangeland Plains, respectively. Blackflies were present in more than 50 percent of stream lengths sampled in the State; mayflies and caddisflies were present in more than 80 percent. Dragonflies were present in a greater percentage of stream lengths in the Rangeland Plains than in the Cultivated Plains.

\section{Introduction}

The Environmental Monitoring and Assessment Program Western Pilot Project (EMAP-West) was undertaken in North Dakota from 2000 to 2003 to develop tools that could be used to produce unbiased estimates of ecological conditions of perennial streams in the State. The EMAP-West for North Dakota was a cooperative effort by the U.S. Environmental Protection Agency (USEPA), the U.S. Geological Survey, and the North Dakota Department of Health. Information from the EMAPWest was used to establish baseline data that can be compared with data obtained from future monitoring and sampling activities. This fact sheet provides information about EMAPWest sampling activities in North Dakota and selected fish and aquatic insects (macroinvertebrates) sampled from streams in ecological regions of the State during 2000-2003.

\section{Ecoregions of North Dakota}

Ecological regions (ecoregions) have been loosely defined as the spatial representations of the interrelations of natural and human factors (Omernik, 1987). In North Dakota, natural vegetation, predominately prairie grass and a patchwork of forests along streams, was established on a variety of soils and topography. Since settlement, considerable animal production, consisting mostly of cattle, and agricultural production of crops, including wheat, barley, sunflowers, canola, sugar beets, soybeans, and corn, has developed across the State. All these factors contribute to the delineation of ecoregions of North Dakota.

North Dakota is covered by four level III ecoregions as defined by Bryce and others (1998): the Northwestern Great Plains, the Northwestern Glaciated Plains, the Northern
Glaciated Plains, and the Lake Agassiz Plain (fig. 1). In another ecological assessment (Stoddard and others, 2005), the USEPA indicated that North Dakota exists within two broader regions: the Cultivated Plains, a flat to gently rolling landscape that has many wetlands and streams, and the Rangeland Plains, a rolling to hilly landscape that has many wetlands but few streams in the northeast and few wetlands but many streams in the southwest (fig. 1).

\section{EMAP-West Sampling Sites}

Sampling sites were selected randomly by a USEPA statistical design (U.S. Environmental Protection Agency, 2000) to represent lengths of perennial streams in North Dakota from which unbiased baseline data would be collected. Of the 65 sites chosen for sampling (fig. 1), 59 sites were sampled for fish and 62 sites were sampled for macroinvertebrates. Samples could not be collected at the other sites because stream conditions were unacceptable. Of the approximately 4,280 miles of perennial streams within the State, approximately 3,860 miles were represented in the fish sampling assessment (2,230 miles in the Cultivated Plains and 1,630 miles in the Rangeland Plains) and approximately 4,070 miles were represented in the macroinvertebrate sampling assessment (2,440 miles in the Cultivated Plains and 1,630 miles in the Rangeland Plains). No samples were collected from the Missouri River. EMAP-West protocols for fish and macroinvertebrate sampling are explained in the Field Operations Manual for Wadeable Streams for the EMAPWest (Peck and others, 2006). Bank electrofishing was used for fish sampling (fig. 2), and kick-netting was used for macroinvertebrate sampling (fig. 3). 


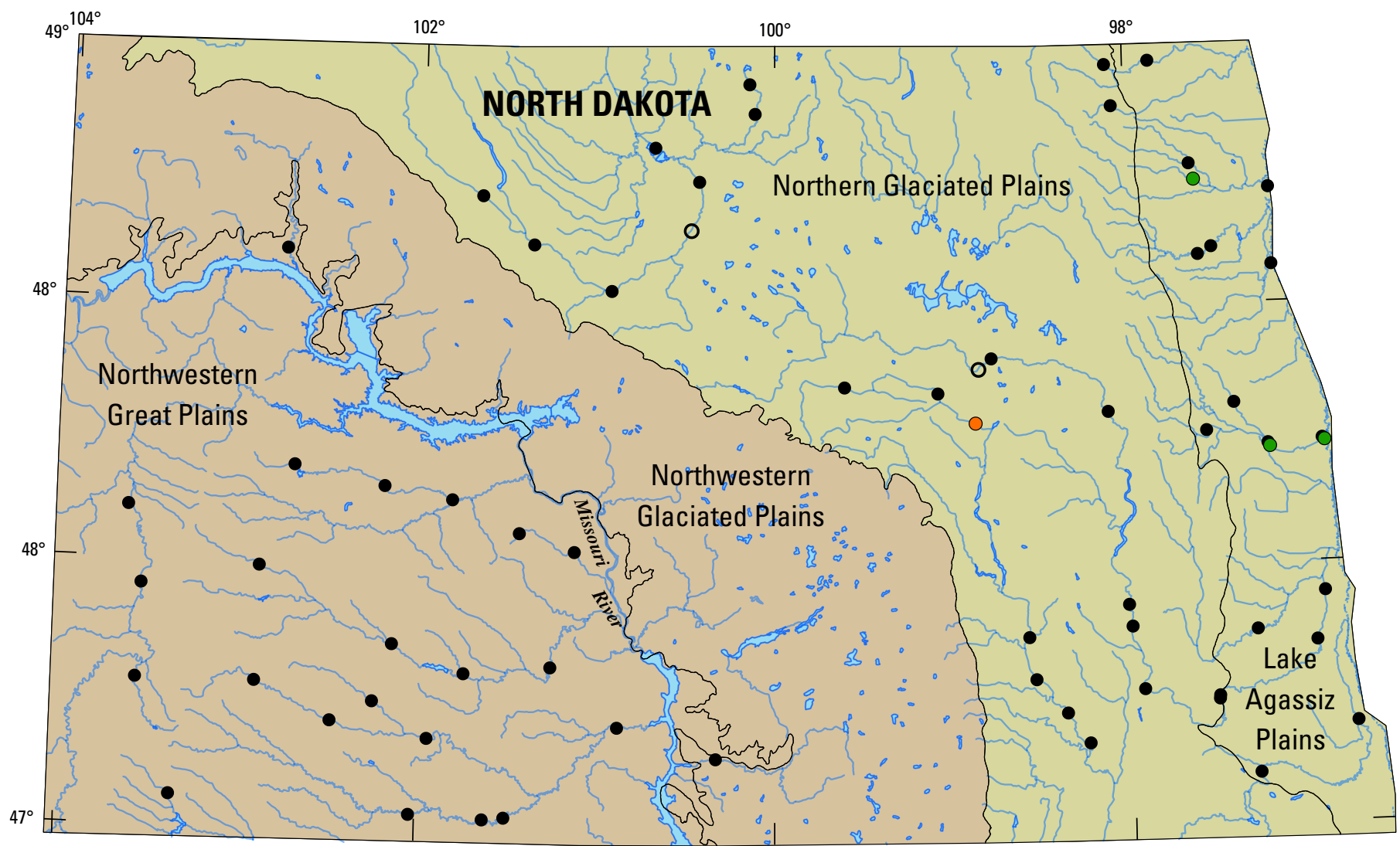

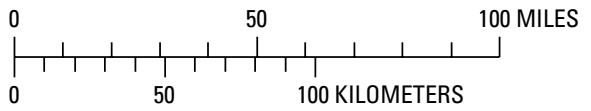

Figure 1. Ecoregions and EMAP-West sites used for sampling fish and macroinvertebrates in North Dakota (adapted from Tom Johnson, USEPA, written commun., 2007).

\section{EXPLANATION}

\section{Sampling site}

- Site visited; fish and macroinvertebrate samples collected

- Site visited; no samples collected because of unacceptable stream conditions

- Site visited; macroinvertebrate samples collected

- Site visited; no fish or macroinvertebrate samples collected

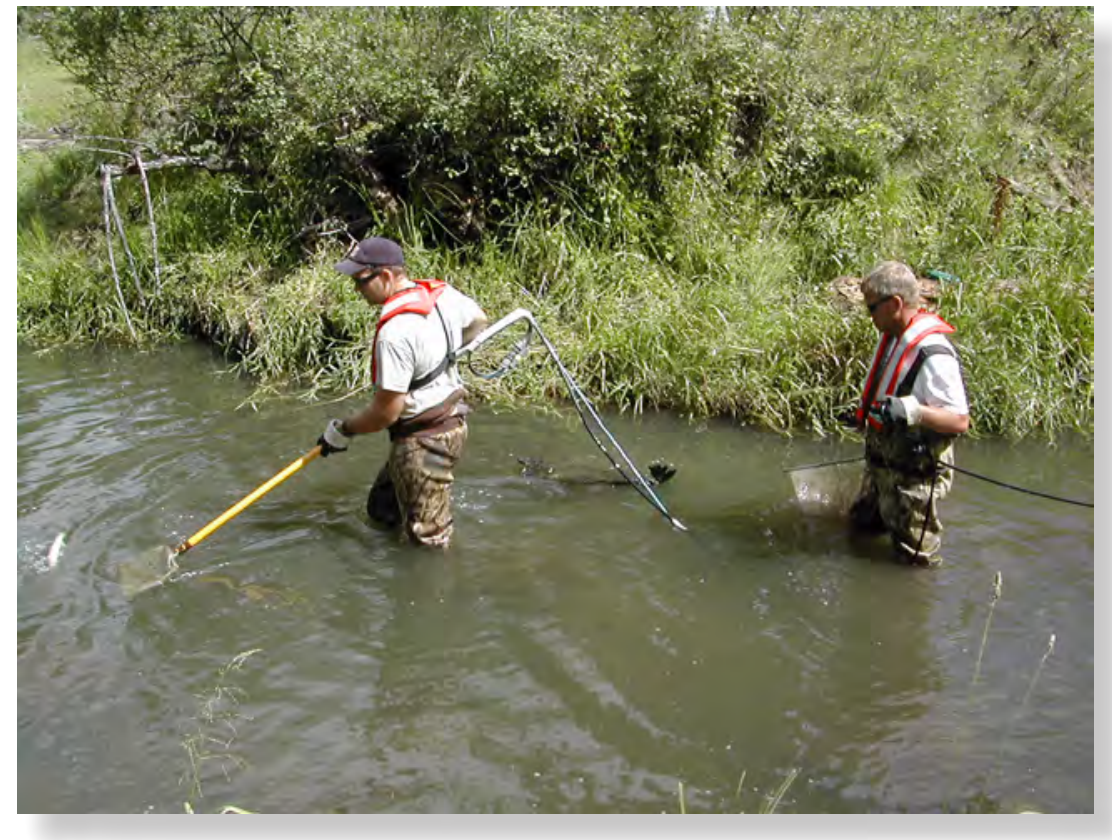

Figure 2. Fish sampling using the bank electrofishing technique.

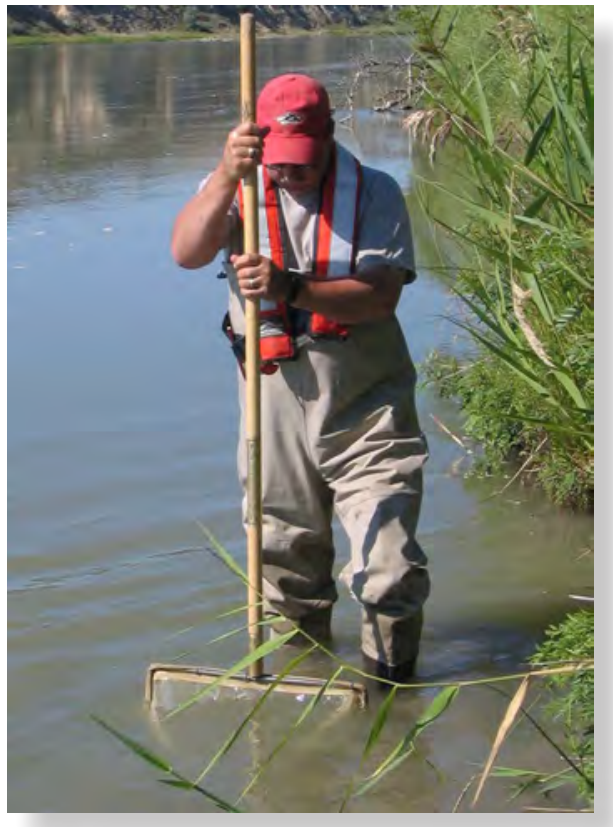

Figure 3. Macroinvertebrate sampling using the kick-netting technique. 


\section{Selected Fish Sampled}

A total of 30,910 individual fish were collected during EMAP-West sampling activities. In all, 56 fish species were identified in the Cultivated Plains (36 sampling sites) and 40 fish species were identified in the Rangeland Plains (23 sampling sites). The most abundant fish sampled were fathead minnows and common shiners. Information on 9 selected game and large fish species (channel catfish, common carp, northern pike, sauger, smallmouth bass, walleye, white bass, white crappie, and yellow perch) are presented.

Of the 22,522 individual fish collected in the Cultivated Plains, only 2,192 individuals were game and large fish species. The most abundant of the game and large fish were channel catfish, which accounted for about 37 percent of the fish collected (fig. 4). Channel catfish are common to the Lake Agassiz Plain ecoregion where many sampling sites were located. The other abundant fish was the common carp, which accounted for one-third of fish collected. The popular game fish northern pike, walleye, and yellow perch each accounted for no more than 11 percent of fish collected. Sauger, smallmouth bass, white bass, and white crappie each accounted for no more than 5 percent of fish collected.
Of the 8,388 individual fish collected in the Rangeland Plains, only 403 individuals were game and large fish species. Common carp, the most abundant fish, accounted for about 33 percent, smallmouth bass accounted for about 27 percent, and northern pike accounted for about 17 percent of fish collected. Channel catfish, walleye, sauger, white crappie, yellow perch, and white bass each accounted for no more than about 13 percent of fish collected (fig. 4).

\section{Selected Macroinvertebrates Sampled}

The percentages of total stream length in the Cultivated Plains region (39 sampling sites) and the Rangeland Plains region (23 sampling sites) that were sampled for each of 5 macroinvertebrate taxa (blackfly, caddisfly, dragonfly, mayfly, and stonefly) are shown in figure 5. Blackflies were present in more than 50 percent of stream lengths in the Cultivated Plains and the Rangeland Plains; mayflies and caddisflies were present in more than 80 percent. Dragonflies were present in 70 percent of stream lengths sampled in the Rangeland Plains but in only about 29 percent of stream lengths sampled in the Cultivated Plains. The stonefly was the rarest of the 5 macroinvertebrate taxa sampled in both regions.

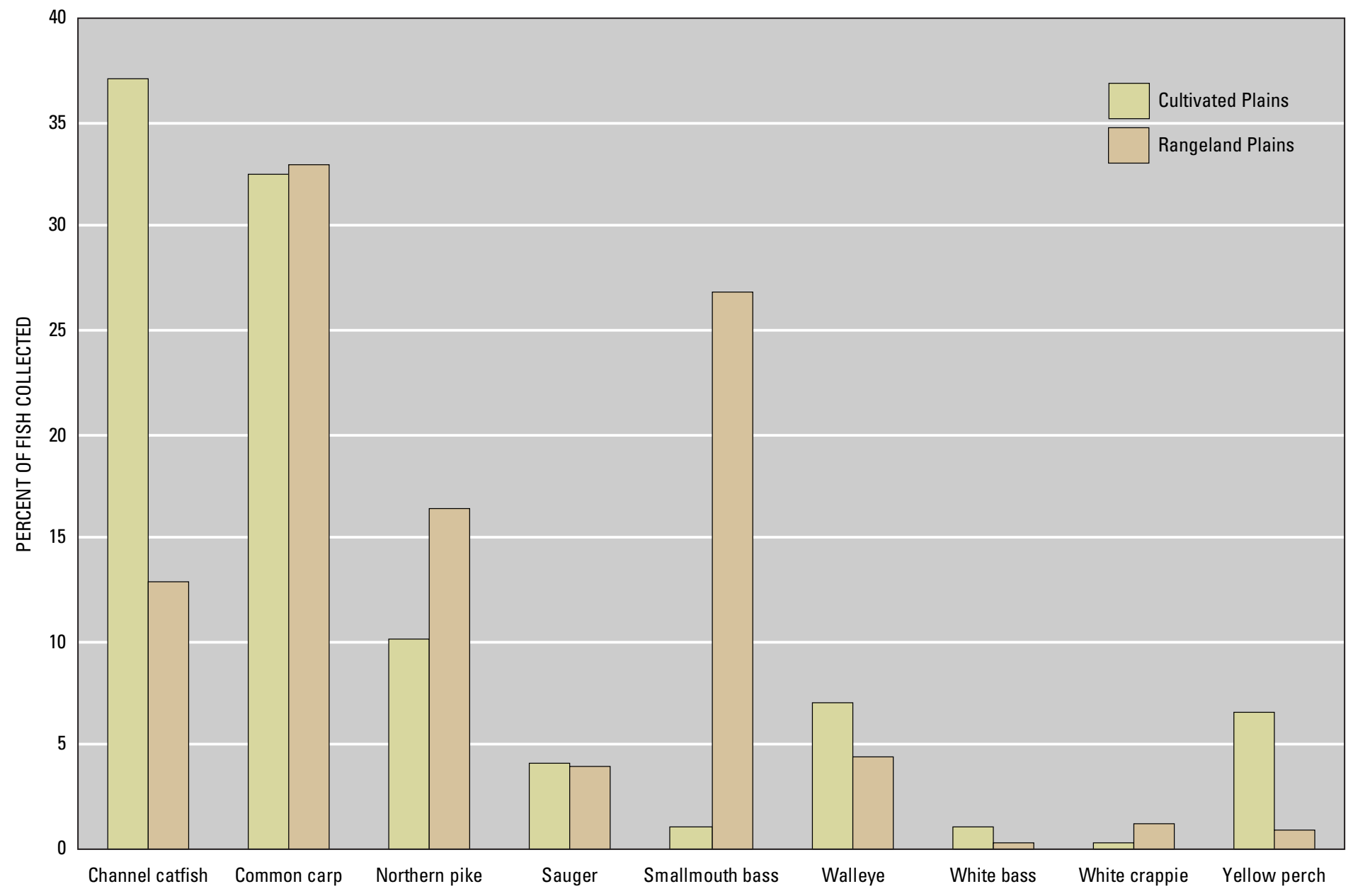

Figure 4. Percent abundance of nine selected game and large fish species collected in streams in the Cultivated Plains and the Rangeland Plains of North Dakota. 


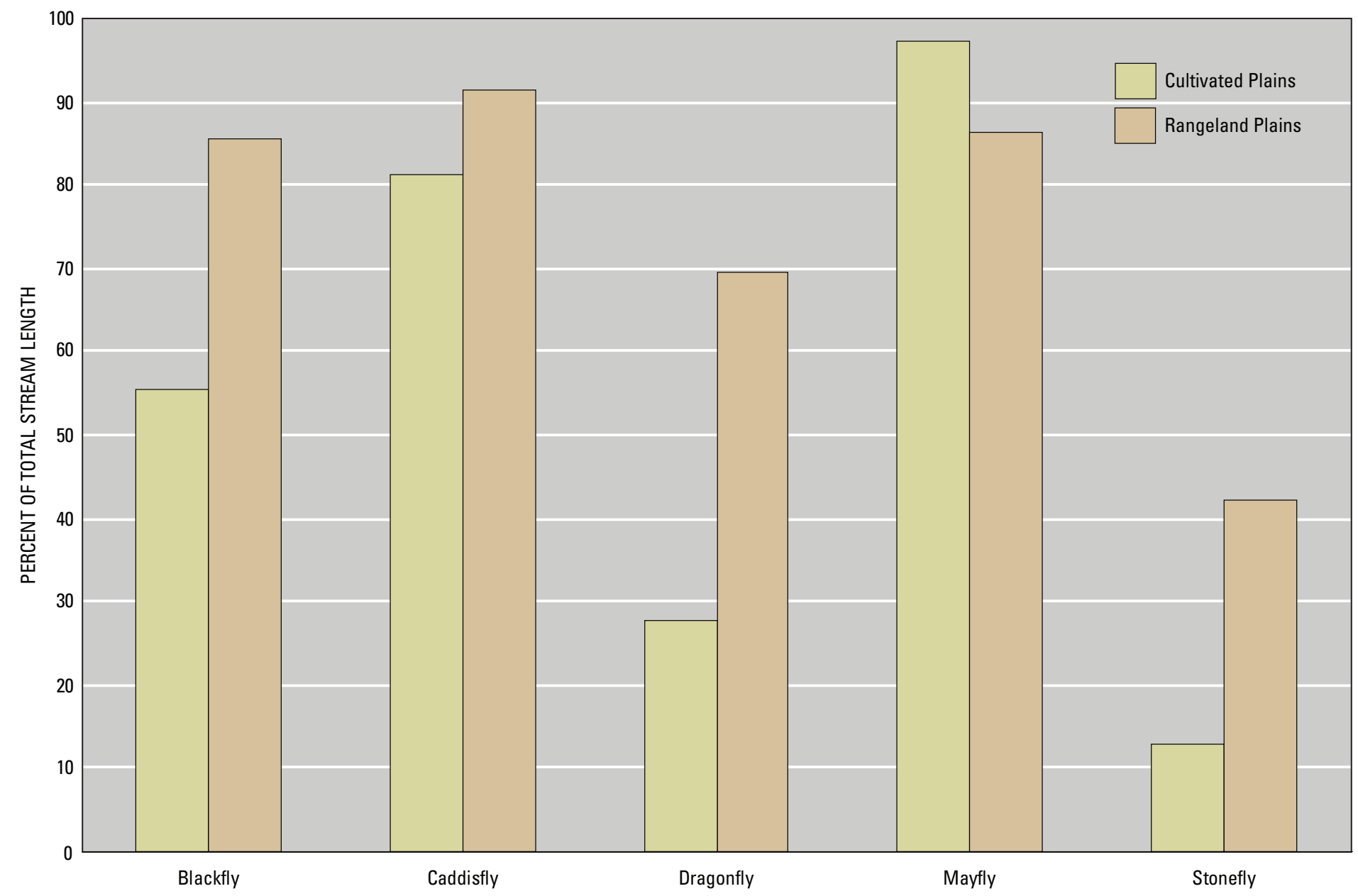

Figure 5. Percent of total stream length in the Cultivated Plains and Rangeland Plains regions of North Dakota that were sampled for each of five selected macroinvertebrate taxa.

\section{References}

Bryce, S.A., Omernik, J.M., Pater, D.E., Ulmer, M., Schaar, J., Freeouf, J., Johnson, R., Kuck, P., and Azevedo, S.H., 1998, Ecoregions of North Dakota and South Dakota: Northern Prarie Wildlife Research Center, Jamestown, North Dakota, accessed August 2007 at http://www.npwrc.usgs.gov/ resource/habitat/ndsdeco/index.htm

Omernik, J.M., 1987, Ecoregions of the conterminous United States: Annals of the Association of American Geographers, v. 77 , no. 1 , p. 118-125.

Peck, D.V., Herlihy, A.T., Hill, B.H., Hughes, R.M., Kaufmann, P.R., Klemm, D.J., Lazorchak, J.M., McCormick, F.H., Peterson, S.A., Ringold, P.L., Magee, T., and Cappaert, M.R., 2006, Environmental Monitoring and Assessment ProgramSurface Waters Western Pilot Study_field operations manual for wadeable streams: EPA Report EPA/620/R-06/003, U.S. Environmental Protection Agency, Office of Research and Development, Washington, D.C. [variously paged].
Stoddard, J.L., Peck, D.V., Olsen, A.R., Paulsen, S.G., Van Sickle, J., Herlihy, A.T., Kaufmann, P.R., Hughes, R.M., Whittier, T.R., Lomnicky, G., Larsen, D.P., Peterson, S.A., and Ringold, P.L., 2005, An ecological assessment of western streams and rivers: U.S. Environmental Protection Agency, Oregon State University, and Dynamac Corporation, Corvallis, Oregon, 49 p.

U.S. Environmental Protection Agency, 2000, MidAtlantic Highlands Streams Assessment: EPA Report EPA/903/R-00/015, Washington, D.C., 64 p.

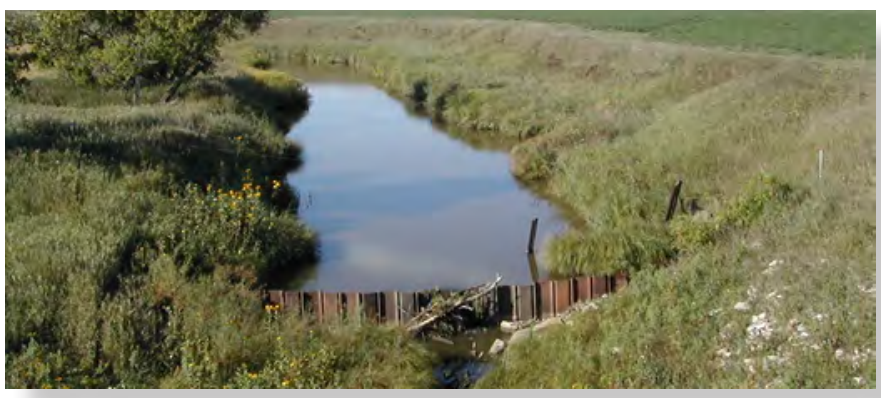

